Original scientific paper

\title{
THE POSSIBILITIES OF LAKE BALATON RESORT AREA IN THE SYSTEM OF THE DEVELOPMENT POLICY 2006-2012
}

\section{A BALATON KIEMELT ÜDÜLŐKÖRZET MOZGÁSTERE A FEJLESZTÉSPOLITIKA RENDSZERÉBEN 2006-2012 KÖZÖTT}

\section{Gergely KABAI}

PTE-BTK-IDI Politikatudományi Program PhD-hallgató

Balatoni Integrációs és Fejlesztési Ügynökség - Társadalomtudományi Kutatócsoport (Lake Balaton Development Agency - Social Science Research Group)

Address: Batthyány U. 1, 8600 Siófok, Somogy

E-mail: kabaigergely@balatonregion.hu 


\title{
A BALATON KIEMELT ÜDÜLÖKÖRZET MOZGÁSTERE A FEJLESZTÉSPOLITIKA RENDSZERÉBEN 2006-2012 KÖZÖTT \\ THE POSSIBILITIES OF LAKE BALATON RESORT AREA IN THE SYSTEM OF THE DEVELOPMENT POLICY 2006-2012
}

Keywords: Balaton, tourism, Hungarian development policy, regional studies, decentralization

\begin{abstract}
:
The Lake Balaton Resort Area (Balaton Kiemelt Üdülökörzet - BKÜ), created in 1996, is Hungary 's second most important tourism destination, and its role in the national economy is significant. The BKÜ has a special position in the development policy system in Hungary. This area is different from the status of NUTS 2 regions: it has less institutional privileges. It was frequently expressed local idea that self-development resources are necessary for the BKÜ, similar to the NUTS 2 regions. This did not happen in 2007-2013; „Balaton development program” or a Balaton Operational Program” was not created in 2007.

The first part of the study reviews the results of BKÜ development, with special attention to the tourism sector. A brief analysis shows that, compared to the prior development period, BKÜ has improved the efficiency of resource acquisition between 2007-2012. The development of tourism was less successful. The vast majority of municipalities in BKÜ not received any tourist resources. Despite the importance of BKÜ significantly fewer resources could acquire. The BKÜ failed to achieve its development goals in the system of the development policy.

The second half of the study seeks to answer why did not achieve self-development resources to the Balaton area. The main reason for this was the centralized operation of the development policy. May be there are many other reasons: party politics, lobbying power, regional attitudes of the government.

Finally special needs of the lake were recognized. That was the so called „Balaton Flagship Programme”. This initiative is practically failed in less than a year. Relevant to the Balaton area, in the three affected ROP there was only minimal co-ordination of tourism development funds.

The study highlights the functioning of the national development policy, the centralized management system and a possibilites of a special area in the period beginning in 2007.
\end{abstract}

Kulcsszavak: Balaton, idegenforgalom, fejlesztéspolitika, területi tudományok, decentralizáció

\section{Kivonat:}

Az 1996-ban létrejött Balaton Kiemelt Üdülökörzet (BKÜ) Magyarország második legfontosabb turisztikai célterülete, így a nemzetgazdaságban betöltött szerepe is jelentös. A BKÜ-nek speciális helyzete van a fejlesztéspolitika rendszerében Magyarországon. E terület státuszában eltér a NUTS2 régióktól, méretében kisebb, intézményi jogosultságai is eltérők. Kiemelt szerepe folytán helyi szinten rendszeresen megfogalmazódó gondolat és igény, hogy NUTS2 régiókhoz hasonlóan önállóan felhasználható fejlesztési forrásokat kapjon a Balaton. A 2007-2013 időszakban erre végül nem került sor.

A tanulmány első fele a BKÜ fejlesztési eredményeit tekinti át, külön figyelemmel a turisztikai ágazatra. A rövid elemzés rámutat arra, hogy a korábbi fejlesztési időszakhoz képest sokat javult a balatoni forrásszerzés hatékonysága 2007-2012 között, de a turisztikai fejlesztéseket tekintve jelentös volt az elmaradás. A BKÜ településeinek óriási többsége semmilyen turisztikai forrásból nem részesült, és a kiemelt fontosságú szezonhosszabbító erejü nagyprojektek is elmaradtak. A súlyához képest a BKÜ jelentősen kevesebb forrást tudott megszerezni. A fejlesztéspolitika meglévő rendszerében a BKÜ nem tudta fejlesztési céljait érvényesíteni.

A fejlesztések elmaradásában nem csak rendszer-szerủ okok játszhattak közbe, de ez is döntő tényező lehetett. Ennek tekintetében a tanulmány második fele arra keresi a választ, hogy miért nem kaphatott önálló fejlesztési forrásokat a Balaton. Ennek fő oka a hazai fejlesztéspolitika centralizált jellegéből adódik. Emellett számos más ok is szóba került: pártpolitikai, lobbi erő, területi szemlélet.

Önálló program helyett a Balaton speciális igényei végül elismerésre kerültek. Több operatív programon átívelő finanszírozási konstrukció gondolatával született meg az ún. Balatoni Zászlóshajó Program. A 
hatáskörök nem egyértelmü lehatárolásával, a centralizált fejlesztéspolitikai rendszer mellett e kezdeményezés gyakorlatilag kevesebb mint egy év alatt megbukott. Végül a Balaton esetében a három érintett ROP-ban csak a turisztikai fejlesztési források kihelyezésének minimális összehangolására került sor. A tanulmány rávilágít a hazai fejlesztéspolitika müködésére, a centralizált irányítási rendszerre és egy kiemelt térség mozgásterére a 2007-től kezdődő fejlesztési időszakban.

\section{BEVEZETÉS}

A Balaton és térsége Magyarország második legfontosabb turisztikai célterülete, amely egyedülálló természeti környezetének, kikapcsolódásra alkalmas vízpartjának, különleges táji adottságainak, valamint a turisztikai igények kiszolgálására létrejött kiterjedt gazdasági-szolgáltatási infrastruktúrájának köszönhető.

Tanulmányomban első felében arra teszek kísérletet, hogy bemutassam a Balaton Kiemelt Üdülőkörzet (továbbiakban BKÜ) fejlesztéseinek Új Magyarország Fejlesztési Terv (ÚMFT), majd Új Széchenyi Terv (ÚSZT) 2007-2012 közötti időszakára eső állapotát. A téma önálló tárgyalása indokolt, hiszen nemzetgazdasági szinten is meghatározó a balatoni idegenforgalom helyzete.

Tanulmányom második felében egy összetettebb probléma megközelítésére teszek kísérletet. A BKÜ fejlesztésének problematikájának hátterét kutatva egy kérdésre koncentrálok: balatoni szinten időszakosan megfogalmazódó igény, hogy a BKÜ fejlesztése lehetőség szerint decentralizált forrásokkal, lokális forráselosztási rendszerrel, egy önálló programmal valósuljon meg. Arra keresem a választ, hogy milyen okok játszhattak abban szerepet, hogy a BKÜ az ÚMFT időszakában miért nem kapott, kaphatott önálló fejlesztési forrásokat? Legvégül mindezt az országos fejlesztéspolitika kontextusába kívánom helyezni. Mindezek a felvetések választ adhatnak arra, hogy a BKÜ milyen mozgástérrel rendelkezett a fejlesztéspolitika érintett időszakában, valamint az időszak kormányainak területpolitikai tevékenységének egy szegmensére is rávilágít.

Elemzésem, különös tekintettel a Balaton térségét érintő politikai háttérfolyamatokra közel sem teljes körü. A kutatás során elért eredmények sokkal több kérdést vetnek fel, mint amennyit képesek megválaszolni. Ennek ellenére reményeim szerint tanulmányom hozzájárulhat a hazai fejlesztéspolitikai, területpolitikai rendszerek teljesebb megismeréséhez, különösen az ÚMFT időszakának vonatkozásában. A felmerülő kérdéseket pedig további kutatásoknak kell egyértelmüsíteniük, így e tanulmány inkább problémafelvető célokat tüzött ki maga elé. 
E dolgozat föként másodlagos források alapján született. Felhasználtam több olyan szakpolitikai értékelés eredményeit, amelyek elkészítésében magam is részt vettem. Ezen felül szakirodalmi források és sajtóanyagok is feldolgozásra kerültek. Ezekkel szerves összefüggésben került sor a vonatkozó szakpolitikai dokumentumok áttekintésére is.

Tanulmányom elméleti rendezőelvét a regionális tudományok területén találtam meg. Nemes Nagy József elmélete szerint, ahhoz hogy egy térségből régió jöjjön létre, három folyamat megvalósulására van szükség. Ezek a regionalizáció, regionalizálódás, regionalizmus. Az első folyamat során térfelosztás eredményeként megszületnek a terület határai; a második folyamat a társadalmi és gazdasági kohéziót kialakulásában játszik szerepet, míg regionalizmus az identitásra és az intézményesülésre épül, amely a kialakuló régió irányítása felé hat. (Nemes Nagy, 2009. 186.)

A következőkben bemutatott folyamatok a fenti aspektusok számos elemére rávilágítanak, közte leginkább az intézményesültség fejlesztéspolitikai vágyaira és vonzataira. Az a tény, hogy az üdülökörzet helyzete a fejlesztéspolitika rendszerében közel sem stabil, rámutat arra, hogy az intézményesülés jelenleg is zajló folyamat. A tanulmányom e folyamat egy rövid, de fontos időszakát járja körül, és reményeim szerint

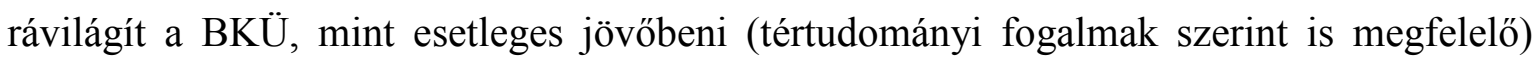
régió kialakulásának törekvéseire.

\section{A BKÜ FEJLESZTÉSE A 2007-2012 KÖZÖTTI IDŐSZAKBAN}

A 2007-2014-es uniós fejlesztési időszakra történő felkészülés idején került kialakításra Magyarország Stratégiai Referenciakerete 2007-2013, amely az Új Magyarország Fejlesztési Terv nevet kapta. Az ÚMFT a turizmusfejlesztési forrásokat a regionális operatív programok (ROP) hatáskörébe utalta. Ennek alapján az európai uniós támogatású turizmusfejlesztés három formában indult meg: turisztikai attrakciók fejlesztése, szálláshelyek megújítása és turisztikai desztináció menedzsment szerveztek kialakítása, fejlesztése.

A Balaton térségének összehangolt fejlesztésére a BKÜ-t az 1996. évi XXI. tv. (A területfejlesztésről és területrendezésről) nevesíti először mint kötelezően létrehozandó kiemelt fejlesztési területet. A törvény a Balaton Fejlesztési Tanács, mint a térség fejlesztéséért felelős szerv is nevesítésre kerül. A BKÜ pontos határait az 89/1997. (V.28) korm. rendelet határozza meg először. A három megyét, (majd a tervezési-statisztikai régiók létrehozásával) három régiót is érintő BKÜ-t kezdetben 154 település alkotta. Az 
ún. Balaton törvény megszületésével 2001-ben a BKÜ 164, majd 2008-ban 179 településre bővült. A BKÜ fejlesztése kezdetben központi költségvetési forrásokból valósult meg. Későbbiekben ezek mellett nagyságrendileg nagyobb szerepet kaptak az európai uniós források.

Három tervezési-statisztikai régióval érintkezve három regionális operatív programban (ROP) van jelen a BKÜ egy-egy területe, így a kiemelt térség fejlesztési intézmények szemszögéböl nem egységes. Mint látni fogjuk, a Balaton Fejlesztési Tanács (BFT) csak a három érintett régió prioritásainak és támogatási konstrukcióinak kialakításában vehetett részt.

Az uniós tervezési-fejlesztési szintnek (NUTS2) megfelelö tervezési-statisztikai régiók határainak megállapítására 1998-ban került sor, amelyek alapvetően három megye összekapcsolásából születtek meg. E régiók kialakítása során a BKÜ területe, amely lényegében idegenforgalmi szempontok szerint került lehatárolásra, nem felelhetett meg az uniós követelményeknek, hiszen területében és lakosságszámában leginkább egy átlagos megye (NUTS3 szint) adottságaival rendelkezik. Ezen felül megyéken, kistérségi határokon átívelő területe további intézményi „bonyodalmakra” adhatott volna okot. (Agg, 2010. 24-25.) Ez az állapot gyakorlatilag elörevetítette, hogy az ÚMFT során egy NUTS2re régiókra tervezett regionális operatív programot nem kaphat a BKÜ térsége.

Végül (mint látni fogjuk) a BKÜ tekintetében az érintett három ROP turisztikai forrásai minimális összehangolásra kerültek és mindegyik ROP-ban külön-külön önálló elemként megjelent a BKÜ illetékes területe. Dél-Dunántúli Operatív Program turisztikai magterületként tekintett a Balatonra, ahol a fejlesztési célok vízi, aktív, konferencia- és egészségturisztikai fejlesztések, tematikus parkok stb. létrehozása a cél. A NyugatDunántúl esetében ökoturisztikai és aktív programok fejlesztések jelent meg célként, míg Közép-Dunántúli OP hagyományos turisztikai térségként tekintett a BKÜ-re. (Pannon.Elemzö, 2013./A.)

A Balaton esetében az I. Nemzeti Fejlesztés Terv (NFT) 2004-2006 közötti időszakára és az Új Magyarország Fejlesztési Terv (ÚMFT) 2007-2008 közötti idejére vonatkozóan 2009-ben született egy elemzés (Oláh - Dombi - Retz, 2009). A tanulmány bemutatta, hogy az NFT-1 ideje alatt rendkívül alacsony hatásfokkal müködött a BKÜ forrásszerzése: az egy före eső fejlesztési források hazai átlagának mindössze $60 \%$-t sikerült lehívni. Hasonlóan alacsony volt a pályázati aktivitás mértéke is (Oláh - Dombi - Retz, 2009 5-7.). 
Az Új Magyarország Fejlesztési Terv első két évére vonatkozóan sem javult jelentősen a helyzet. A szerzők végezetül arra a következtetésre jutottak, hogy a vizsgált időszakban a „BKÜ hátrányosan került ki a forrásokért vívott versenyböl. Ahogy azt az NFT-I idöszakára vonatkozóan ki kellett jelentenünk, az ÚMFT első két évének forrás-kihelyezési gyakorlata során sem volt érvényesithetö az üdülökörzet többlet igénybevételböl (turizmus, környezetvédelem) eredeztethetö kiemelt státusza. Amennyiben ezek az arányok a tervezési idöszak hátralevö részében jelentös mértékben nem változnak, akkor a régió nagy valószinüséggel hosszú időre elveszitheti egykori versenyképességét." (Oláh - Dombi Retz, 2009. 29.)

Az ÚMFT/ÚSZT 2007-2012 márciusának időszakában az országban több mint 76000 pályázatot adtak be, amelynek 3\%-a esett a BKÜ területére. A támogatott pályázatok aránya a BKÜ-ben és a teljes Magyarországon is közel azonos, csaknem $50 \%$ volt. Az igényelt támogatás összességéből közel 3\%-ot igényeltek az üdülőkörzeten belül (mintegy 263 milliárd Ft-ot), ebböl 2012. év elejéig 175 milliárd Ft. lekötött forrás érkezett a térségben. A vizsgált időszakban mindössze csak 45 milliárd (26\%) került kifizetésre.

A fejlesztési források egészét tekintve a BKÜ az ÚMFT/ÚSZT 2012. év elejéig terjedő időszakában jelentősen javított forrásszerzési képességein, bár sok tekintetben így is elmarad az országos átlagtól; (méretének megfelelően) megyei szintü összehasonlításban a középmezőnyben helyezkedik el.

Pályázati aktivitást vizsgálva a BKÜ javított korábbi állapotához képest. Ezer főre vetítve a BKÜ-ben 8,86 pályázatot nyújtottak be, míg az országos átlag mindössze 7,38 darab volt. (1. ábra) (Kabai, 2012.) 


\section{1. ábra. Ezer főre eső pályázatok száma ÚMFT/ÚSZT 2012.03.-ig}

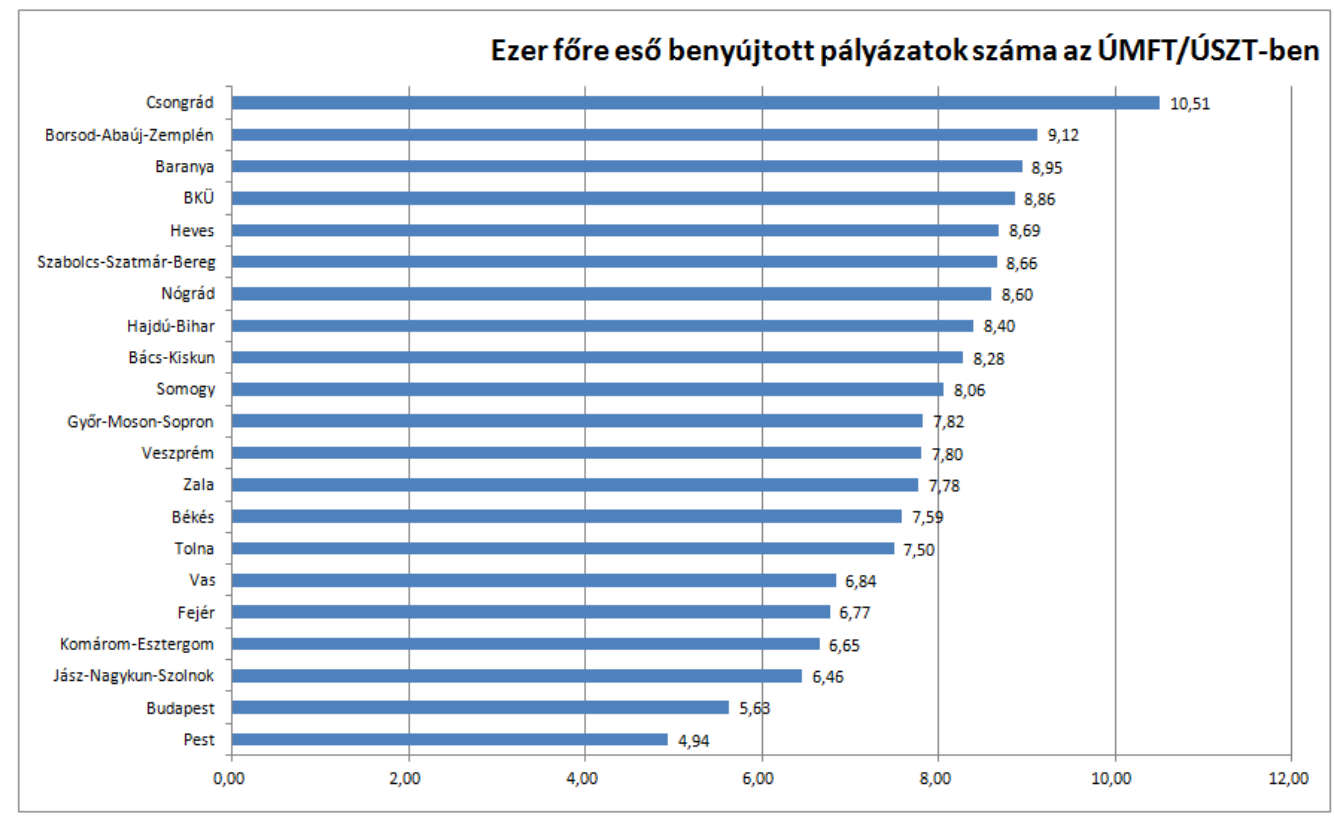

Forrás: Kabai, 2012

A 2012 tavaszáig kifizetett fejlesztési források tekintetében a BKÜ viszont már közel sem ért el jó eredményeket. A 2011-es állandó népesség adatokkal számolva egy före eső országos átlagban mintegy 244 ezer Ft esett, a BKÜ esetében ez az összeg csak 165 ezer Ft. A BKÜ egy före vetít kifizetett források tekintetében az országos átlag csak alig több mint 76\%-át érte el.

A megítélt támogatások egy före eső arányát tekintve a BKÜ valamivel az országos eredmény fölött teljesített. Az ország egész területét tekintve $601882 \mathrm{Ft} /$ fő eredményt mérhetünk, addig ugyanebben az időszakban a Balatonnál 637816 Ft/fő támogatást ítéltek meg. (2. ábra) 


\section{2. ábra. Egy főre eső fejlesztési források összehasonlítása}

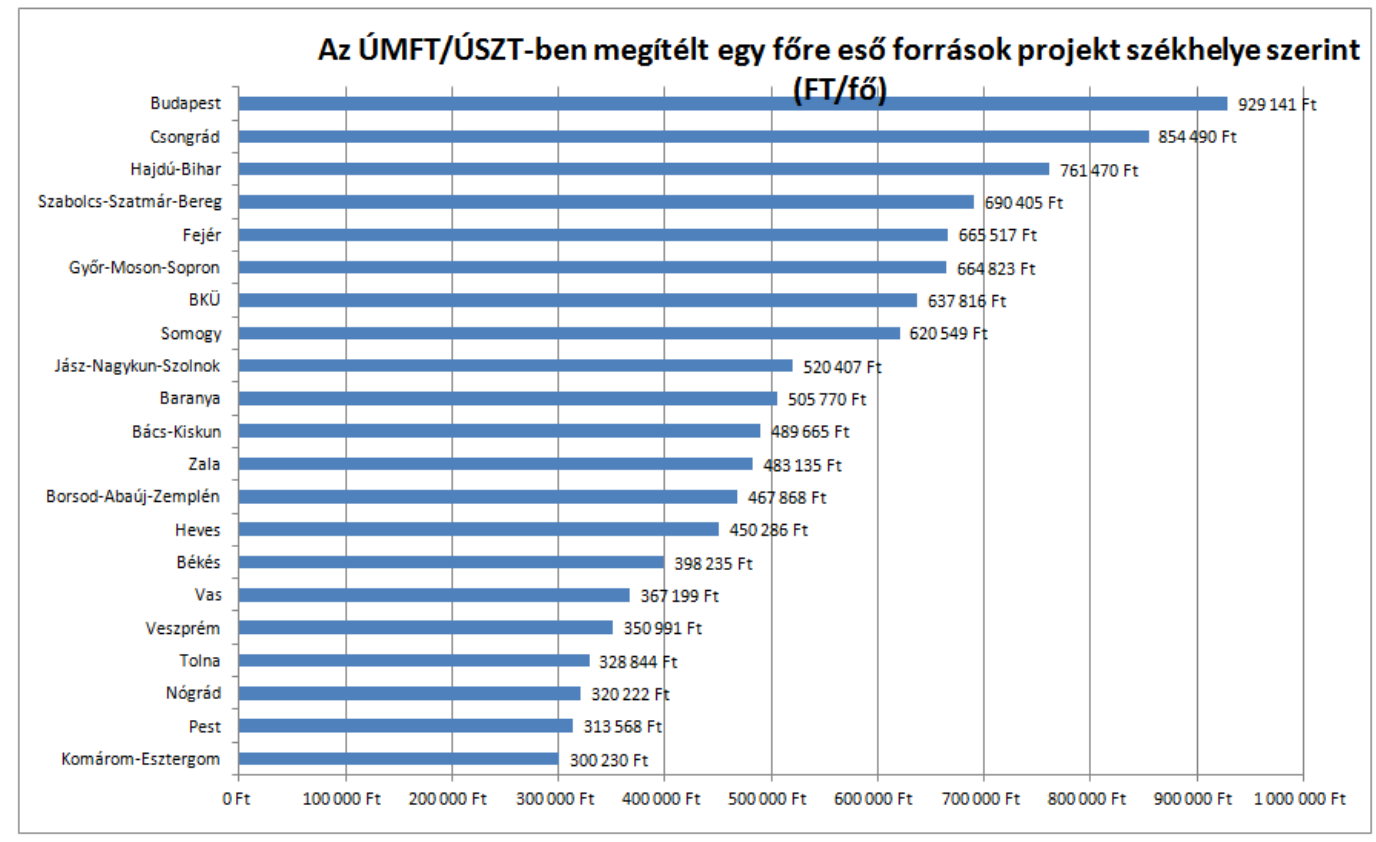

Forrás: Kabai, 2012

A forrásszerzés hatékonyságát mutatja, hogy a pályázatok során igényelt összeg mintegy 66,5\%-t sikerült a BKÜ területén fejleszteni kívánó pályázóknak elnyernie, ezzel országos összehasonlításban is kiemelkedő eredményt ért el e terület.

Az ÚMFT/ÚSZT 2012. év elejéig terjedő időszakában a korábbiakhoz képest nőtt a balatoni forrásszerzés hatékonysága, de ténylegesen kifizetett fejlesztési források tekintetében jelentősen elmaradt az országos tendenciáktól.

Az összes fejlesztési forrás megszerzésével ellentétben a BKÜ húzóágazatát jelentő idegenforgalom fejlesztésében nem voltak kiemelkedő sikerek.

A turizmusfejlesztés területi kohézió szempontú értékelése címü vizsgálat során elsősorban a regionális operatív programok keretei között megpályázható turizmusfejlesztési források kerültek elemzésre. A 2007-2012. augusztusa közötti időszakban a BKÜ esetében 381 turisztikai pályázat adatait (országos 14\%-a) vizsgálta az értékelés, amelyekhez kapcsolódóan mintegy 18 milliárd Ft megítélt turisztikai támogatást lehetett megállapítani. Ez az összeg a teljes hazai megítélt turisztikai fejlesztési források alig több mint 8\%-a.(PannonElemző, 2013./A) A Balaton hazai turizmusban betöltött szerepének ismeretében ez a forrásszerzési eredmény rendkívül csekély, amely már elöre vetíti az ágazat fejlesztésének problémáit. Szintén ezt támasztja alá, hogy az összes nyertes turisztikai pályázat csak mintegy $16 \%$-a esett a BKÜ területére. 
A számos fejlesztési cél között megfogalmazott balatoni nagyprojektek, szezonhosszabbító beruházások elmaradását kiválóan példázza, hogy az 500 millió Ft felett pályázatok az országosnál jelentősen kisebb arányban vannak jelen, arányuk csak mindössze 4\%-volt. A fejlesztési források és a kisebb beruházások túlsúlyát mutatja, hogy az országosnál nagyobb arányban szerepelnek 50-100 millió Ft közötti projektek, és 100500 millió Ft közöttiek is elmaradnak hazai viszonylatban. (PannonElemzö, 2013./A)

A balatoni turizmus-ágazat területileg rendkívül koncentrált és egy-egy város köré csoportosul főként a szálláshelyek-vendégéjszakák tekintetében. Ez a kiegyenlítetlen rendszer a pályázatok száma és a források megszerzése során is érvényesült. A legtöbb projekt a partmenti településekre koncentrálódott, közülük is kiemelkedett Balatonfüred, Siófok, Tihany, Keszthely. A partközeli, illetve háttértelepülések közül csak Hévíz, illetve Zalakaros említhető. A pályázati rendszernek a turizmus dekoncentrációját nem sikerült elősegítenie, sőt ellentétes hatásokat váltott ki. (PannonElemző, 2013./A)

A leszerződött támogatási összegek tekintetében is hasonló koncentrációt találunk: Balatonfüred 2,5 milliárd Ft összeggel a lista élén áll, míg Siófok, Zalakaros és Tihany 1-2 milliárd Ft közötti támogatást nyert el, 18 település pályázói 100 millió és 1 milliárd Ft közötti összeggel rendelkeznek elviekben, míg további 19 településen 100 millió Ft alatti összeget nyertek el. A BKÜ 138 települése (77\%) semmilyen leszerződött turisztikai támogatással nem rendelkezett a vizsgált időszakban. (PannonElemző, 2013./A)

A fejlesztések sikerességének fontos mutatója lenne, hogy a rendelkezésre álló források közül mennyit tudott megszerezni e terület. A BKÜ abszorpciós képességeinek vizsgálata során azonban jelenleg komoly adathiányba ütközünk.

A három érintett ROP 2007-2010 közötti akcióterveinek elemzése alapján az attrakciófejlesztés, vonzerőnövelés, valamint turisztikai együttmüködések fejlesztése (TDM szervezetek) célokra a három érintett ROP-ban összesen 10,67 milliárd Ft állt a BKÜ rendelkezésére. A szálláshelyfejlesztések esetében egyik akcióterv sem különített el forrásokat a BKÜ számára, így ezt a forráskeretet külön nem tudjuk tárgyalni. A 20112013-ra vonatkozóan viszont a jelenleg nyilvános ROP Akciótervek nem olyan részletesek, hogy az egyes prioritások részleteit is tárgyalják, így a BKÜ egyes külön forrásairól sem kaphatunk számszerüsíthető adatokat. (ROP Akciótervek 2007-2010)

A különböző fejlesztési dokumentumokban megfogalmazott, eröteljesen az idegenforgalomra építő Balaton fejlesztési irány tekintetében, az ÚMFT első 2/3-ának időszaka nagyrészt sikertelen volt. A fejlesztéspolitika rendszerében a balatoni 
idegenforgalom fejlesztésének kiemelt célját a BKÜ-nek nem sikerült érvényesítenie. Elmaradtak a szezonhosszabbító, tömegeket vonzó nagyberuházások, és látványos nagyprojektek. A források elaprózódtak. Az összes turizmusfejlesztési forrás csekély arányát sikerült a Balatonhoz irányítani, amely kiemelt státusza, de a hazai turizmusban romló helyzete miatt viszont szükségét látná. A turizmus területi megoszlását sem sikerült előmozdítani, hiszen a BKÜ településeinek 3/4-ét semmilyen idegenforgalom fejlesztési forrás nem érintette. Emellett a fejlesztési célok közül komplex fejlesztési csomagok sem tudtak megvalósulni.

Összességében: ,a BKÜ térsége fejlettségi es jövedelmi viszonyait tekintve az országos átlag alá került, így, kiemelt turisztikai szerepre való tekintettel, fejlesztéshez támogatások szükségesek. Ugyanakkor a 2007-2013-as ciklusban a BKÜ-re meg turisztikai súlyához képest is kevesebb fejlesztési pénzt allokáltak. Ennek jövöbeli változatlansága esetében a térség turisztikai versenyképessége kritikussá válik." (PannonElemzö, 2013./A) (PannonElemzö, 2013./A)

\section{A BKÜ MOZGÁSTERE AZ ÚMFT TERVEZÉSE ÉS MEGVALÓSÍTÁSA SORÁN}

A fentiek során azért tárgyaltam viszonylag hosszan a BKÜ-t érintő fejlesztési tendenciákat, hogy bemutassam, hogy a rendelkezésre állt fejlesztéspolitikai keretekben e terület nem tudott akkora forrásokat lekötni, mint az helyzetéböl adódón szükséges lett volna. A következökben e helyzet kialakulásának hátterét vázolom.

A fejlesztéspolitika Balaton esetében tapasztalható területi ellenmondásaira világít rá, hogy a BKÜ területe három ROP között oszlott meg, így bizonyos értelemben perifériális pozícióba került; számos nélkülözhetetlen fejlesztés elmaradt. „Ez rámutat a térség egységes fejlesztéspolitikai kezelésének szükségességére (intézmény, forrás). Ráadásul az OTK elismerte, hogy a térség közszolgáltatási kapacitásai, fejlesztési igényei nem csupán állandó lakosainak igényeit kell, hogy kielégítse, hanem a mintegy 240 ezer fönyi üdülötulajdonosi körét is, továbbá az itt megjelenö turisztikai forgalmat is ki kell szolgálni. Ez a fejlesztéspolitikában nem érvényesül. Az országos, és föleg a vidéki átlagot sokszorosan meghaladó társadalmi igénybevétel okozta amortizációs és környezetvédelmi következmények kezelése a területpolitika kiemelt figyelmét követeli meg, ami átlagot meghaladó fejlesztési források régióba áramoltatását és helyben integrált módon történö felhasználását igényli." (PannonElemző, 2013./A) 
A fenti problémák megoldására a helyi szereplők részéről az elmúlt évtizedben sokat hangoztatott gondolat, hogy a térség fejlesztését valamilyen önálló program formájában lenne célszerű megvalósítani. Ennek kapcsán a kérdés az, hogy 2006-2007-ben az országosan is kiemelt fejlesztési státusza ellenére végül miért nem kapott önálló fejlesztési forrásokat a BKÜ?

E kérdés vizsgálata önmagában a hazai területfejlesztési szakpolitika, területpolitika 2000-es évek közepén tapasztalható helyzetére, illetve ezekkel szoros összefüggésben az ÚMFT tervezésének és működésének alapjaira is rávilágít. Ezen felül e téma Balaton térségének érdekérvényesítő képességének kérdését is árnyalja.

Mint egy korábbi elemzés rámutatott, az önálló fejlesztési program elmaradásán kívül még számos más tényező közrejátszott abban, hogy 2007-2014 közötti időszakban a BKÜ korlátozott eredményeket ért el. Ezek közül több is kiemelkedö hatású lehetett, így az általam tárgyalt kérdés, csak a probléma egyik oldalát világítja meg:

- Az érintett ROP-ok belül a BKÜ viszonylag kis forrásokat allokáltak, amely nem volt elegendő minden fejlesztési igényre.

- Kevés projektötlet született és források hiányában szinte teljesen elmaradt a projektgenerálás.

- Gyenge volt a fejlesztési szereplők közötti együttműködés.

- A helyi szereplők tőkeszegények. (PannonElemző, 2013./A. 77-78.)

A Balaton önálló fejlesztésének gondolata egyidős a balatoni turizmus-gazdaság megjelenésével és erősödésével, amely már közel 130 évre vezethető vissza.

Intézményileg, forrás-kihelyezési tapasztalatait tekintve a Balaton Fejlesztési Tanács és háttérszerve készen állt arra, hogy 2007-től egy önálló programot müködtessen. 1999-től kezdődően évente változó mértékben, de BFT számos hatáskörébe átutalt főként központi költségvetési forrás kihelyezését valósította meg. A központi források átengedésével pl. 2005-ben már 1,1 milliárd Ft felett döntött a BFT. (Kaiser, 119.)

A fejlesztési források valamilyen önálló program keretében történő megszerzésére már az I. Nemzeti Fejlesztési Tervre (NFT) történő felkészülés során felmerült az igény. A BFT 2002-2006 közötti fejlesztési tervében szerepel: „A térségben lévő önkormányzatok részéről erös az igény az önálló területtel rendelkezö önálló régióra, amely ezáltal a tervezési-statisztikai EU támogatási célterülete lehetne. (...) El kell érni, hogy a Balaton közvetlenül is, és három régión keresztül, illetve azokkal való együttmüködésben is 
megjelenhet az Európai Uniós forrásokban..." (Idézi Oláh, 2002. 52.) (Fentebb már utaltunk rá, hogy ez az időszak a Balaton számára végül abszolút sikertelen volt.)

A korábbi önállóan felhasználható fejlesztési források feletti rendelkezés és gyakorlat tekintetében a 2007-2013-re történő felkészülés idején az első tervezési dokumentumok kivétel nélkül egy saját programmal rendelkező BKÜ-ről szóltak. Ezt erősítette a Gyurcsány-kormány kommunikációja is, amely helyi hatáskörökbe utalt (nem csak uniós) források kihelyezését vetítette előre. „Csökkentjük a pántlikázott pénzek számát, csökkentjük a központi pályázatokat, hogy ennek forrásait oda lehessen adni a régiónak, a megyének, a településnek. Azaz csökkentjük a központi kormányzat feladat-elöiró, feladatfinanszírozó kiegyenlitő szerepét, ezzel növeljük a helyiek felelösségét." - emelte ki pl. Gyurcsány Ferenc miniszterelnök 2005-ben egy rendezvényen. (idézi Simon, 2005.)

Ezzel a szemlélettel született a 2005 nyara - 2006 év eleje között elkészülö és elfogadásra kerülö Balaton Stratégia, valamint az országos dokumentumokba ágyazott Balaton Térségi Komplex Program is. Mindkét dokumentum szerint a BKÜ önálló fejlesztési programmal kell, hogy rendelkezzen.

Mivel 2006 év közepén még mindig nem született semmilyen előzetes döntés egy önálló Balaton programról, így a fenti dokumentumok operatív forrás-kihelyezési tervvé történő átalakítása (Részletes Balaton Terv 2006) előre vetítve a jövőt, már más-más OPkből finanszírozható projektekre, illetve a három érintett ROP-ból közösen megvalósítható fejlesztésekre koncentrált. (Péti, 2006. 34-36.)

2006 nyarán a helyi szereplők még reménykedtek egy önálló Balaton program elindulásában. A helyi önkormányzatokat tömörítő Balaton Szövetség nevében Dr. Bóka István Lamperth Mónika turizmusért és területfejlesztésért felelős miniszterhez intézett interpellációt a parlamentben. „Dr. Bóka István azt kérdezte a minisztertől, hogy lesz-e önálló balatoni regionális program elkülönitett, csak a Balaton kiemelt üdülökörzetre felhasználható pénzekkel? Ha nem, akkor a tó körüli három jogi régió programjaiban lesznek-e csak az üdülőkörzetre felhasználható pénzek?” (Veszprém megyei Napló, 2006. július 26. $)^{1}$

Egy nem sokkal később született tanulmány helyesen világítja meg az akkoriban fellépő problémát: „Éppen ezért a 2007-2013 közötti programidőszak előkészitésének egyik sokat vitatott kérdése volt, hogy megjelenjen vagy megjelenhet-e az ÚMFT-ben a

\footnotetext{
1 (Ismeretlen ok miatt) az interpelláció eredeti szövege nem szerepel az Országgyülés internetes gyüjteményében.
} 
Balaton fejlesztési programja akár önálló OP, prioritás, esetleg kiemelt program formájában, avagy a BFT-nek külön-külön kell megállapodnia a három régióval a Balaton fejlesztését érintö kérdésekröl az NFÜ által menedzselt komplex program keretében. A BFT és a KDRFT egységesen - bár nyilvánvalóan eltérö érdekektöl vezérelve - az elöbbi javaslatot támogatta, azonban az NFÜ álláspontja 2006 augusztusában már elöre vetítette a második verzió megvalósulását." (Kaiser, 2007. 119)

Ez a bizonyos esemény, ahol már lényegében egyértelmüvé vált az önálló Balaton program elmaradása, 2006 augusztusában zajlott Veszprémben. A Közép-Dunántúli Regionális Fejlesztési Tanács ülésén felszólaló Bajnai Gordon (ekkor) fejlesztéspolitikai kormánybiztosként egyértelműen a NUTS2 régiók szerepe mellett kötelezte el magát. (Veszprém Megyei Napló, 2006. augusztus 31.)

2006 késő őszén az ÚMFT ROP-ok társadalmi egyeztető fórumán újra felmerült a BKÜ kérdésköre. Ebben az időszakban a kormány részéről már megjelent az a gondolat, hogy ha nem önálló program formájában, de a három érintett régió egyeztetésével kapjon kiemelt szerepet a BKÜ. „Ami a régiós önkormányzati müködést illeti és az ezekhez kapcsolódó fejlesztéseket a régiókban majd részletesen egyeztetjük. Önálló szempontként megjelent a Balaton és a komplex programok jelentősége. A Balatonnal úgy számolunk, mint egy komplex programmal, és nem, mint régióval, hiszen az uniós statisztikai nomenklatúra erre nem ad lehetöséget, de arra igen, hogy olyan programokat készitsünk, amely egy-egy célzott problémakört érintenek. Ilyen értelemben a Balaton, mint önálló zászlóshajó projekt elindítását tervezzük." - emelte ki a rendezvényen Bajnai Gordon fejlesztéspolitikai kormánybiztos.

Ezt a felszólalást egészítette ki ugyanezen az eseményen Dr. Szaló Péter államtitkár az Országos Területfejlesztési Minisztérium képviseletében: „Felmerült az egyik kérdésben, hogy lesz-e Balatoni Fejlesztési Tanács. Lesz és müködni is fog és reméljük, hogy nagyon sikeres lesz még akkor is, ha nem lesz végrehajtó, hiszen nem lesz ilyen operatív program, de ezt senki soha nem is igérte. A végrehajtást nem tovább aprózni kívánja a kormányzatamivel egy Balatoni OP együtt járna -, hanem a hatékonyság irányába terelni. Ami nem jelenti azt, hogy komplex programok ne tudnának úgy megvalósulni, hogy a lábai különbözö operatív programokba érjenek. Az a kérdés, hogy van-e ilyen jó program, van-e olyan zászlóshajó, ami tudja szervezni a Balaton térségében a legföbb célokat: a minőségi turizmust és a környezetvédelmet. Az a komplex program, ami mindent tartalmaz az 
agráriumtól a humán infrastruktúra-fejlesztésig, az nem komplex program." (ROP-ok társadalmi egyeztetése, 2006.)

Ezek a megszólalások jellemzik azt az időszakot, amely az Balaton térségének ÚMFT időszakára történő felkészülését kísérte, és végül nem jöhetett létre egy önálló fejlesztési program. A következőkben azokat az okokat igyekszem feltárni, amelyek a program elmaradásához vezettek.

Az önálló Balaton OP elmaradásának legfőbb okaként alapvetően az intézményistrukturális szempontokat tartjuk. A 2007-13-as fejlesztési időszak NUTS2 régiókra épülő szemlélete meghatározta a kereteket, amelyeken a hazai tervezők és szakpolitikusok nem kívántak túllépni. Ezt támasztják alá az előbbi nyilatkozatok is, amelyek az uniós struktúrákra hivatkoznak. Ilyen körülmények között nehezen elképzelhetö lett volna, hogy NUTS2-es régiók rendszere megbontásra kerüljön és egy önálló OP-t kapjon a BKÜ.

Árnyalja a folyamatokat, hogy ebben az időszakban a fejlesztéspolitika rendszerében a BKÜ-höz képest a NUTS2 régiók sem voltak jelentősen elönyösebb helyzetben. Elönyük elsősorban csak annyi volt, hogy e szintre épült fel a fejlesztések rendszere, illetve méretüknél fogva esetleg komolyabb lobbi-tevékenységet fejthettek ki. Ezt erősítette, hogy 2006 őszétől a regionális fejlesztési tanácsokban alapvetően a kormányoldal dominanciája érvényesült. (Perger, 2010. 12.)

Már az I. NFT idején tapasztalhatók voltak azok a folyamatok, melyek a vártnál kisebb hatáskört adtak a fejlesztési régióknak. A 2004-2006 közötti időszakban a viszonylag kis forrásokat kaptak a regionális programok, és rendkívül kis hatáskört szereztek a NUTS2 régiók szervei azok elosztásában. (Perger, 2010. 10.)

Az 2007-2014 közötti fejlesztési időszakra történő felkészülés során a régiók nagy reményekkel fordultak a kormány felé. Ezt ösztönözte, hogy a 2004-ben megalakuló Gyurcsány-kormány programja szerint egyértelműen a regionális szint mellett kötelezte el magát. „A közigazgatás átalakitásának iránya a decentralizáció és a regionalizáció lehet. A kormány vallja, hogy a döntéseket a lehetö legközelebb kell meghozni az emberekhez. Bízunk a polgárokban, bízunk a helyi közösségekben, hiszen ök, az érintettek tudják a legjobban, mire van szükségük. A döntéshozatal decentralizálása, az önkormányzatiság erösitése egyben a lehetőségek és felelösségek kiterjesztését is jelenti. (...)A decentralizálás és az önkormányzatiság jegyében elősegitjük a térség jövőjét meghatározó fejlesztési döntéseknek a régiók, a kistérségek szintjére történö telepitését. A feladatot, a megvalósitásához szükséges pénzt és a felelösséget is azoknak kell átengedni, akik erre a 
legilletékesebbek, a kisebb és tágabb helyi közösségeknek. (...)Központi forrásokat biztositunk a Nemzeti Fejlesztési Tervvel összhangban megvalósuló regionális és kistérségi fejlesztésekhez, önálló döntést biztositva a Regionális Fejlesztési Tanácsoknak és a Kistérségi Fejlesztési Tanácsoknak.” (Lendületben az ország..., 2004.)

2006 májusában az új kormány programja szintén hasonló célokat fogalmazott meg. A program a fejlesztéspolitika alapvető területi szerveként ismét a NUTS2 szintü régiókat határozta meg. „Az önkormányzati reformmal a területfejlesztés feladatai a regionális önkormányzatokhoz kerülnek.(...) A regionális testületek forráselosztó és monitoring feladatokat kapnak." (Új Magyarország, 2006.)

Az előzetes elképzelések ellenére a régiók számára nyújtott lehetőségek egészen eltérő képet mutattak. 2006. májusi választásokat követően a politikai eseményei, illetve a fejlesztéspolitika kettős irányítása mellett ${ }^{2}$ lezajlott viták a régiók számára végül nem túl nagy mozgásteret engedtek. A 2007-14-re eső fejlesztési források csak mintegy 25\%-át kapták meg a ROP-ok (korábbi 50\%-os tervek ellenére). Emellett a regionális operatív programok irányításában is rendkívül csekély hatáskört kaptak a regionális intézmények. A fejlesztési döntési hatáskörök regionális szintre történő átadását végül a 2006 őszi választások döntötték el, ahol a megyék többségében a jobboldali ellenzék győzött. A kormány a régiókat nem tekintette legitim politikai szereplőknek, így nem kívánt komolyabb mechanizmusokat átruházni. A regionális fejlesztési tanácsok a korábbiakhoz képest több (véleményezési, döntési) hatáskört kaptak, de a ROP-ok irányítása lényegében a központilag müködő Iránytó Hatóság hatáskörébe került. (Perger, 2010. 11-13.)

Egy ilyen erős központi rendszerben, ahol a NUTS2 régiók és ROP-ok is csak korlátozott mértékben voltak képesek önmaguk számára hatásköröket szerezni, egy alig megyényi területtel bíró fejlesztési régió eleve rendkívül nagy hátránnyal indult, hogy egy teljes OP-t kapjon. (Csak feltételezni tudjuk, hogy mérvadó okként jelent meg az is, hogy a három érintett NUTS2 régió valószínüleg nem szívesen mondott volna le a rendelkezésére álló források feletti döntésről, hogy azokat átadják a BKÜ számára.)

A helyi szereplők gyenge érdekérvényesítő lehetőségei is rávilágítanak arra, hogy az ÚMFT teljes időszakában (majd az Új Széchenyi Terv során is) a fejlesztéspolitika teljesen centralizáltan müködött.

\footnotetext{
${ }^{2}$ A fejlesztéspolitika területén ebben az időszakban müködött egy illetékes miniszter (Lamperth Mónika) és egy önálló kormánybiztos (Bajnai Gordon).
} 
Az önálló felhasználású balatoni források elmaradásának hátterében még további okok is feltételezhetőek.

Feltehetőleg nagyon távolt állt az időszak szakpolitikusaitól az a föderatív szemlélet, amely szükséges lett volna egy decentralizáció irányába mutató fejlesztéspolitikai döntés meghozatalához. Ezt a folyamatot láttuk a tervezési-statisztikai régiók kapcsán, a kormányprogramokban lefektetett célok ellenére. Ezt a gondolatomat egy 2007-es parlamenti eseménnyel tudjuk illusztrálni. 2007 áprilisában a BKÜ önkormányzatainak képviseletében Bóka István kérdést intézett Lamperth Mónika területfejlesztési ügyekért felelös miniszterhez, amelyben a Balatonhoz érkező és saját hatáskörben felhasználható források csökkenő mennyiségének problémáját veti fel, valamint a turisztikai fejlesztések elmaradásának veszélyét vázolja. A miniszter azonnali válaszában a BKÜ-t érintő intézményi megoldások problémáját lezárva válaszolt: „Az intézményes garanciáknál pedig, ha azt gondolja képviselö úr, hogy a Balaton Fejlesztési Tanácsnak úgy kellene döntési kompetenciákat szerezni, hogy nem egyeztet a döntéshozóval, a kormánnyal, akkor azt kell mondjam, ezt nem támogatjuk.”(Lamperth Mónika felszólalása az Országgyülésben 2007.04.23)

Az önálló balatoni forráskeret, vagy kiemelt program elmaradásának egy lehetséges (bár közvetlenül nem bizonyítható) oka lehet politikai ellentét is, amely baloldali MSZP kormány és az alapvetően jobboldali helyi politika között állt fenn. A Balaton térsége egy hagyományosan jobboldali-konzervatív vidék. 1947-et megelőzően is hagyományosan a kormánypárti konzervatív pártok nyerték a választásokat a Balaton körül. E jobboldali kötődés 1990-es választásokat követően is megmutatkozott. (Ez alól csak az 1994-es választások hoztak kivételt, amikor a Balaton térségének mindegyik egyéni választókörzetében az MSZP ért el sikereket). A 2007-2013-es fejlesztési időszak tervezésének évében „a 2006 évi választás a balliberális kormányzat pártjaival szembeni ellenzéki föerők lehengerlö gyözelmét eredményezte a Balaton térségében." A FideszKDNP a listás szavazatok 50,76\%-át szerezte meg a térségben, míg az első fordulóban 4 választókörzetben e párt jelöltjei az egyéni képviselői helyeket is megnyerték, míg a 2 másik érintett körzetben a második fordulóban értek el sikereket az ellenzéki pártok. A kormánypártok a Balaton térségében egyáltalán nem értek el sikereket. (Dombi, 2006.)

Az önálló fejlesztési források elmaradásának egyik fontos oka lehetett a Balaton MSZPSZDSZ kormányon belüli alacsony hatásfokú képviselete is. A kérdéses időszakban a Balaton Fejlesztési Tanács élén Dr. Sütő László, Marcali város polgármestere állt, a 
kormány delegáltjaként. A BFT elnöke egy 2005-ös interjújában a Balaton fejlesztésének több lehetséges irányáról nyilatkozott. Ebből a beszélgetésből kiderül, hogy Sütő László a turizmusfejlesztésében elsősorban az önkormányzatok szintjét tartotta kiemeltnek, nem a régiót. A következő fejlesztési időszak Balatont érintő tervezésében elsősorban konszenzusos megoldást tartott elképzelhetőnek. „... a térség fejlesztése se lehet csupán a térségi szereplök vagy a központi kormányzat kizárólagos felelössége. A központi, a regionális, a kistérségi és a helyi aktivitások ki kell egészitsék egymást." Az interjúból kiderült, hogy a megyei lobbik erejét a megkérdezett erősebbnek tartotta, minthogy területfejlesztésileg a BFT-részére a korábbiaknál több forrást, hatáskört engedjenek át. A beszélgetés alapján úgy tűnhet (bár igazolni nem tudom), hogy a BFT elnökének abban az időszakban alapvetően a meglévő status quo fenntartása volt a célja, és nem kívánt a megyei(regionális) érdekekkel szemben erősebben képviselni a BKÜ érdekeit; annak ellenére, hogy többször hangsúlyozta a térségbe érkező fejlesztési források növelésének szükségességét. (Comitatus - Interjú Sütő Lászlóval, 2005.)

A Balaton térség tervezési időszakban mutatott lobbi erejét jól illusztrálja, hogy az ÚMFT parlamenti politikai vitájában 2006 őszén már egyetlen felszólaló sem említette meg a Balaton önálló fejlesztési programjának gondolatát, szükségességét. (www.parlament.hu - 2006.10.17. ülésnap)

Mindezek a fenti tényezők együttesen eredményezhették a BKÜ önálló programjának elmaradását. Ennek ellenére a kiemelt balatoni fejlesztési célok legalább részben elismerésre kerültek a fejlesztéspolitika részéröl. Megszületett a Balaton térségének ágazati és területi operatív programokon átívelő komplex fejlesztési programjának ötlete. Ennek bejelentése, mint fentebb láttuk, már 2006 őszén megtörtént.

A Balatoni Zászlóshajó nevet kapott komplex program tervezése 2007 tavaszán indult el. Ez a megoldás egy önálló programhoz képest jelentős visszalépést jelentett. Lamperth Mónika a program tervezéséröl egy parlamenti felszólalásban csak annyit említett, hogy „..örvendetes az együttmüködés a Balaton Fejlesztési Tanáccsal, hiszen közösen fogjuk kidolgozni a Balaton zászlóshajó projektet, ami Balatonfürednek és a többi balatoni térségnek is érdemi fejlödést és fejlesztést hoz majd." (Lamperth Mónika felszólalása az Országgyülésben 2007.04.23.)

A program összefoglalása szerint: ,A Balaton Zászlóshajó Projekt átfogó célja, hogy a balatoni régió a természetesség és a magas életminöség mintarégiója legyen. Ehhez a Balaton térség és a müködö vállalkozások versenyképességének, valamint a területi 
kohézió és a környezetminöség javitása szükséges. Az elmúlt években elkészült a balatoni zászlóshajó koncepció, amely mindegy száztízmilliárd forint uniós támogatás felhasználását tartalmazza.”(A Zászlóshajó programról - BFT honlapja, é.n.) (A későbbi források már 163 milliárd Ft-ról szólnak.)

„A fejlesztések forrásai különbözö operatív programokban kerülnek lehatárolásra, a zászlóshajó projekt önálló kerettel nem rendelkezik. Mindez érinti a három régió, valamint a szektorális területek programjait. Egyes fejlesztési területek esetén, ahol a 3 régió vonatkozásában a Balaton menti fejlesztések összehangolására van szükség a 3 ROP-ból nyílik lehetöség a balatoni pályázatok finanszírozására, a térségi szempontú koordinációval. A koordináció az Önkormányzati és Területfejlesztési Minisztérium feladata" (A Zászlóshajó programról - BFT honlapja, é.n.)

A zászlóshajó program gyakorlatilag minden helyi problémára és fejlesztési elképzelésre igyekezett forrásokat meghatározni a BKÜ számára. A fó hangsúlyt a turizmus fejlesztése kapta, de megjelent a civil közösségek, munkaerőpiac, gazdaság, környezetvédelem, stb. támogatása is. Sőt még az Új Magyarország Vidékfejlesztési Program bizonyos lehívható támogatásaira is javaslatot tett a program. A BFT elviekben véleményezési szerepet kapott az OP-k akcióterveinek készítése, projektjavaslatok benyújtása során. (Balatoni Zászlóshajó Program, 2007. 05. 31.) Egy olyan komplex program született meg, amelynek épp összetettségéből eredően már sejteni lehetett a működési nehézségeit. (Ezt a fenti idézetben Szaló Péter államtitkár már előrevetítette.)

A program bejelentését nagy sajtóvisszhang, pozitív várakozások kísérték. A nagyívü elképzelések ellenére a Zászlóshajó programról nagyon hamar kiderült, hogy müködésképtelen. A koncepció elkészülte után kevesebb mint egy évvel (2008 áprilisában) Suchman Tamás a BFT (Sütő Lászlót) követő elnöke már bejelentette a ,zászlóshajó elsüllyedését."

A program bukásának okai önálló elemzéseket igényelnének, de feltehetőleg a számos szereplő közötti koordináció hiánya, az egységes programirányítás, a döntési hatáskörök túlszervezettsége okozta a legnagyobb gondot. Jelenleg ez még nyitott kérdés. „Az egységes döntéshozatal hiánya miatt a balatoni zászlóshajó program nem müködhet tovább, a tervezett fejlesztések ezért csak külön valósulhatnak meg - mondta Suchman Tamás a Balaton Fejlesztési Tanács és a Balatoni Idegenforgalmi Bizottság együttes ülésén." (vehír.hu, 2008.04.03.) 
A BFT elnök bejelentésének néhány részletét és a kapcsolódó reagálásokat érdemes idézve bemutatni egy országos napilap közlése nyomán.(Népszabadság, 2008. 04. 17.)

„A program az eredeti tervek szerint nem müködhet tovább. Arra ugyanis nincs elkülönített, önálló forrás - mondta érdeklödésünkre Suchman Tamás. - Emiatt ugyan nem kerülnek veszélybe a fejlesztések, de azok megvalósitása a vártnál jóval nehezebb, bonyolultabb lesz. Az elnök szerint a változás lényegében annyi: egy önálló keret hiján külön-külön kell majd a programban szereplö egyes beruházások fedezetéért pályázni a kormánynál, a BFT-nél és a tavon "osztozó" három régiónál. Hozzátette: így pedig csak szigorú koordinációval, gyakori egyeztetéssel, valamint a BFT, a dél-, a nyugat-és középdunántúli régió szoros együttmüködésével sikerülhet a fejlesztések megvalósitása."

A BFT elnökének véleményét, így a zászlóshajó program bukását Bajnai Gordon (ekkor már) területfejlesztésért felelős miniszter sem tudta érdemben megcáfolni. Nyilatkozatával lényegében lezárta a Balaton 2007-2013 közötti fejlesztésének akkor már közel két éve húzódó problémáját, és a NUTS2 régiók mint a BKÜ ügyében is meghatározó fejlesztési szereplők mellett érvelt:

„A balatoni zászlóshajóprogram céljai maradéktalanul érvényesülnek - mondta (...) Bajnai Gordon önkormányzati és területfejlesztési miniszter. Hozzátette: az viszont tény, hogy a programban megfogalmazott turisztikai tervekhez rendelt fejlesztési források elosztása a tó speciális helyzete miatt nem volt viták nélküli. Mint mondta, turisztikai szempontból hiába egységes a Balaton, az mégiscsak három régió határán van. Ebben a három régióban pedig nem csak a Balaton turisztikai fejlesztésére van szükség. Ezt a különleges helyzetet éppúgy szem elött kellett tartani a források elosztása során, mint azt, hogy a tó adottságai az egész ország számára fontosak, kiemelt figyelmet érdemelnek.

A három régió a legszívesebben maga döntött volna az egész rendelkezésre álló fejlesztési forrás felhasználásáról, miközben voltak olyan balatoni törekvések, amelyek szerint a regionális tanácsok mellett müködö BFT-nek kellett volna még nagyobb összeget kiszakitani - mondta Bajnai Gordon. - Végül az eltérö érdekeket figyelembe véve, nagyon kemény alku során osztottuk el a BFT és a három régió között a turisztikai fejlesztésekre forditható pályázati forrásokat. Ezzel helyzetbe hoztuk a régiókat, de az egységes balatoni fejlesztés érdekében a BFT-t is."

A kép teljességéhez érdemes a Balaton Szövetség nevében megszólaló Bóka István véleményét is idézni: 
hiányzik a politikai szándék a térség átfogó fejlesztésére. Bebizonyosodott az is tette hozzá -, hogy a második nemzeti fejlesztési terv intézményrendszere alkalmatlan a több ágazatot összefogó, komplex fejlesztésekre. Bóka István ugyanakkor egyetértett abban a BFT elnökével és Bajnai Gordonnal, hogy a fejlesztési tanács, valamint a régiók rendelkezésére álló forrásokból sikerülhet a zászlóshajóprogramban szereplö beruházásokat - vagy legalábbis azok többségét - megvalósitani." (Népszabadság, 2008. 04. 17.)

Így ért véget a BKÜ önálló fejlesztésének kísérlete az ÚMFT időszaka során. A továbbiakban csak a Zászlóshajó program egyfajta kiüresített verziója kísérte végig a fejlesztési időszak Balatont érintő külön történet, és mint láttuk csak a turizmusfejlesztési források 3 ROP közötti részleges összehangolása maradt meg a közös fejlesztési célokból.

A fentiek figyelembevételével végső soron rendkívül korlátozott sikernek tarthatjuk, hogy a BKÜ végül mindhárom érintett ROP-ban, saját BKÜ ,alrégiójára” vonatkozóan kapott egy-egy elkülönített, egymástól csaknem független turizmusfejlesztési forráscsomagot. Ez mutatja, hogy a Balaton lobbi ereje csak rendkívül korlátozottan tudott hatni fejlesztéspolitika rendszerére. Emellett rávilágít arra is, hogy a fejlesztéspolitika hazai tervezői végig tisztában voltak a Balaton különálló fejlesztésének szükségességével, valamint a helyi turizmus-ágazat prioritásával, de ezt az intézményrendszerbe már képtelenek voltak érdemben beépíteni.

Az már ettől független kérdés, hogy (mint láttuk) a BKÜ helyi szereplöi végül nem tudtak teljes mértékben élni a megmaradt turizmusfejlesztési lehetőségekkel sem: hiányoztak a tőkeerős befektetők, a gazdasági válság jelentősen visszavette a fejlesztési kedvet, az önkormányzatoknak nem voltak erőforrásaik és ténylegesen hiányzott a BKÜ életéből egy erős projektgeneráló szerv.

\section{KÖVETKEZTETÉSEK}

Nem tudjuk egyértelműen állítani, hogy egy valamilyen egységes balatoni program ÚMFT keretei közötti megvalósítása végül teljesen másfajta fejlesztési eredményeket generált volna az elmúlt években, vagy sokkal több sikeres projekt tudott volna létrejönni, esetleg javult volna a BKÜ relatív gazdasági, fejlesztési helyzete. Ebben a kérdésben számos más tényező is közrejátszott. E tanulmány csak ezt az egy aspektust kívánta bemutatni.

A Balaton szempontjából rendkívül sikertelen 2004-2006 közötti csonka fejlesztési év után minden helyi szereplő abban bízott, hogy a következő 7 évben egy a BKÜ 
szemszögéből sikeresebb időszak következik. Egyértelmü törekvés volt a saját hatáskörben elosztható forráscsomag megszerzése. A fent bemutatott okok (strukturális, politikai, lobbi) miatt e források megszerzése végül elmaradt. Mindez kiválóan példázta, hogy a BKÜ-nek csak rendkívül korlátozott gazdasági-politikai érdekérvényesítő eszközök álltak rendelkezésre.

Végül a fejlesztéspolitikai rendszer és intézmények hálózatának rendszerén a köztes megoldást jelentő, operatív programok között kapcsolatot teremteni próbáló Balatoni Zászlóshajó program is megbukott 2008 év elejére.

Mindezek együttesen hozzájárultak ahhoz, hogy bár a források megszerzésének mutatóiban a korábbiakhoz képest jelentősen javított a BKÜ, de a turizmusfejlesztésben az eredeti célok tükrében csak rendkívül korlátozott eredményeket ért el. Így az ÚMFT első időszakában, kb. 2012 év elejéig (ameddig elemzésünk látószöge kiterjed) gyakorlatilag minimálisan erősödhetett a balatoni turizmus és gazdaság versenyképessége.

A BKÜ példája a hazai fejlesztéspolitikai rendszer müködésének számos elemét tovább árnyalja, amely összecseng egy a közelmúltban lezárult szakpolitikai értékelés több megállapításával, amely a területiség szempontjait vette szemügyre. (A területi koordinációs kapacitások vizsgálata - PannonElemző, 2013/B).

Az ÚMFT/ÚSZT-re vonatkozó elemzés egyik fö megállapítása, hogy „A magyar fejlesztéspolitika centralizáltan müködik. A fejlesztési célokat, eszközöket központilag határozták meg, a végrehajtás logikáját és döntéseit mechanizmusait ugyancsak a kormányzat szempontjai határozzák meg, a konstrukciók müködtetését is központilag irányitották."(PannonElemző, 2013/B) A Balaton esete ezt abszolút alátámasztja, hiszen minden végső döntés kormányzati szinten került végső eldöntésre, nem jöhetett létre egy decentralizált fejlesztési színtér.

Az elemzés megállapításai szerint a területi koordináció a fejlesztések végrehajtása során a tervezői szándékokban foglaltaknál kevésbé érvényesült. Az egyes szereplők nem kezdeményeztek a saját feladataik elvégzését nehezítő együttműködéseket.(Pannon.Elemző, 2013/B) Bár a Balaton esetében a Zászlóshajó program esetében pont egy együttmüködési kísérlet megvalósításának próbáját érintettük. Kudarca pontosan ezt támasztja alá: a számos fejlesztési szereplő közötti együttmüködése területi szinten abszolút nem tudott kézzelfogható eredményt hozni a fejlesztéspolitika rendszerében. 
Az értékelés szerint „a források elosztásának rendszerében a helyi szereplők csak nagyon kevéssé tudtak beleszólni." (PannonElemzö, 2013/B) Bár a BKÜ fejlesztési szereplöinek mindvégig lehetséges konzultációs szerepe volt, de maradéktalanul nem tudta érvényesíteni érdekeit. Ugyanakkor a BKÜ-t alkotó településeknek önállóan sem volt jelentős esélye, hogy saját maguk vagy térségüknek többlet-forrásokért lobbizni tudjanak.

A kutatás eredményei szerint a források megszerzésében a nagyobb népességü, nagy gazdasági erejü, vagy jelentős pályázati humánkapacitást felmutató helyi szereplők szállhattak versenybe. Lényegében ez eredményezte azt, hogy a BKÜ-n belül jelentősebb turisztikai forrásokat csak az ágazatban meghatározó városok (Balatonfüred, Keszthely, Siófok, Hévíz, Zalakaros) tudtak megszerezni.

A fent vázolt problematika alátámasztja azt, hogy 2006-tól kezdődően a hazai fejlesztéspolitika határozottan koncentráltan, felülröl irányítva müködött. Az alsóbb területi szinteknek rendkívül kevés beleszólásuk volt a források elosztásának rendszerébe, vagy esélyük önálló források megszerzésére. Mindez következett önmagából a fejlesztési rendszerből, valamint a szakpolitikát irányító döntéshozók területiséggel kapcsolatos szemléletéből.

A tanulmányunkban megvilágított problémák napjainkban különösen aktuálisak. Egy új (a korábbitól jelentősen eltérő szemléletü) uniós fejlesztési időszak küszöbén, 2013-ban, hasznos lenne, ha a fejlesztéspolitika rendszere el tudná kerülni korábbi buktatóit.

A 2014-túl kezdődő uniós fejlesztési időszak több új eszközt vezet be a területfejlesztés eszközrendszerében. Ezek közül az egyik az ún. ITI, integrált területi befektetések. ${ }^{3}$ Az ITI rendszere lehetővé teszi különböző operatív programok prioritásainak, ágazati céloknak a közös, összehangolt, egységben megvalósuló fejlesztését. Számos ágazatot és szereplőt érintő kérdés a Balaton fejlesztésének problémája. Az egymással szoros összefüggésben lévő célok (vízminőség, turizmus, természetvédelem, mederkotrás, stb.) intézményi áthidalására az ITI rendszere alkalmas lehet. Ennek indokoltságát mutatja, hogy közel sem garantált, hogy 2014-től kiemelt fejlesztési feladatokat felvállaló középszint (megyék) alkalmas lesz az így továbbra is perifériálisan elhelyezkedő BKÜ megoldandó céljainak elérésére.

Az ITI összekapcsolható a területfejlesztés másik új eszközével, a CLLD rendszerével (közösség által irányított helyi fejlesztések). A balatoni turizmus rendszerében nagy

\footnotetext{
${ }^{3}$ ITI-röl bővebben lásd: Integrált területi befektetés http://ec.europa.eu/regional_policy/sources/docgener/informat/2014/iti_hu.pdf
} 
hagyománya van a közösségi irányításon alapuló turisztikai desztináció-menedzsment szervezeteknek (TDM). A már müködő szervezetek szakmai tapasztalatuk és helyi beágyazottságuk révén a CLLD rendszerén keresztül alkalmasak lehetnek a BKÜ turizmusának alulról történő fejlesztésére. Az ITI és a CLLD eszközének felhasználásával a Balaton fejlesztése a jövőben új irányokat vehet.

\section{FELHASZNÁLT IRODALOM}

Tanulmányok, elemzések:

Agg, Z.(2010). Mi értelme van a megyerendszer vizsgálatának? Comitatus Önkormányzati Szemle. XX. évf. 187. szám. 21-35.

Dombi, G. (2006). Országgyülési választások a Balaton térségében. In.: Tanulmányok a 2006-os önkormányzati választásokról. Comitatus - Önkormányzati szemle. XVI. évf. 2006. évi Különszám. 82-137 p.

Kabai, G.(szerk.) (2012). A Balaton Régió jelene és jövője. Társadalmi-gazdasági-vízügyi helyzetkép. A Balatoni Integrációs Ügynökség megbízásából készítette Pannon.Elemző Iroda Kft. Keszthely. Kézirat.

Kaiser, T.(2007). Közép-Dunántúl, az innovatív megoldások régiója. in.: Kaiser Tamás Ágh Attila - Kis-Varga Judit (szerk.): A régiók Magyarországa I. - A regionális intézményrendszer körvonalai. Budapest.

Nemes Nagy, J. (2009). Terek, helyek, régiók - A regionális tudomány alapjai. Budapest.

Oláh. M.(2002). Az érintettek többségén nem múlik. Vélemények és javaslatok a Balaton régió területi kérdéseiröl. Comitatus - Önkormányzati Szemle. XII. évf. 7-8. szám. 52-72.p.

Oláh, M. - Dombi, G. - Retz, T.(2009). Veszithet versenyképességéböl a Balaton! A Balaton Kiemelt Üdülőkörzet pályázati aktivitása és forrásszerzési eredményessége az NFT - I.-II. időszaka alatt. Comitatus - Önkormányzati Szemle. XIX. évf. 182. szám.

(Pannon.Elemzö, 2013./A) A turizmusfejlesztés területi kohézió szempontú értékelése. A Nemzeti Fejlesztési Ügynökség megbízásából készítette Pannon.Elemző Iroda (konzorciumvezető). Kutatásvezető: Dr. Szabó Pál. Budapest, 2013. http://www.nfu.hu/a_turizmusfejlesztes_teruleti_kohezio_szempontu_ertekelese letöltve: 2013. 06.13.

(PannonElemző, 2013./B) A területi koordinációs kapacitások vizsgálata". A Nemzeti Fejlesztési Ügynökség megbízásából készítette Pannon.Elemző Iroda (konzorciumvezető). Vezető értékelő: Szepesi Balázs. Budapest, 2013. http://www.nfu.hu/a_teruleti_koordinacios_kapacitasok_vizsgalata Letöltés ideje: 2013. 06.13

Perger, É.(2010). Az EU „regionális” támogatások hatása a területi decentralizáció folyamataira. Comitatus - Önkormányzati Szemle. XX. évf. 187. szám 3-21. p.

Péti, M.(2006). A Részletes Balaton Terv elözményei 2007-2013 fejlesztési ciklus tervezésében. Comitatus - Önkormányzati Szemle. XVI. éfv. 7-8. szám. 34-44. 


\section{Sajtóhírek, interjúk:}

A Balaton jelene és jövője - Interjú Sütő Lászlóval a BFT elnökével. Comitatus Önkormányzati Szemle. 2005. augusztus-szeptember. XV. évf. 8-9. szám. 67-72. p.

Az elveszett zászlóshajó. Vita a balatoni fejlesztési program forráselosztásáról. (sajtóhír) Népszabadság Online 2008. 04. 17. http://nol.hu/archivum/archiv-488758?ref=sso letöltés ideje: 2013. augusztus 23. 10:54.

Együtt a Balatonért - Suchman Tamás szerint meghalt a Balatoni Zászlóshajó Projekt. (sajtóhír) vehír.hu. 2008.04.03. http://vehir.hu/cikk/2008-04-03/egyutt-a-balatonertsuchman-tamas-szerint-meghalt-a-balatoni-zaszloshajo-projekt letöltést ideje: 2013. augusztus 23. 10:34

Hátrányosabb helyzetben a tó (újsághír). Veszprém Megyei Napló. 2006. július 26. http://veol.hu/belfold/hatranyosabb-helyzetben-a-to-1383140

Jelszó: Egész évben Balaton! (A Balatoni Zászlóshajó program ismertetése a BFT honlapján.)

http://www.balatonregion.hu/balatoni_gazdasagi_forum/public/menu.php?m=388 letöltés ideje: 2013. augusztus 23. 10:12

Közösen dönthetnek (újsághír). Veszprém Megyei Napló. 2006. augusztus 31. http://veol.hu/hirek/kozosen-donthetnek-1382241 Letöltés ideje: 2013. augusztus 22. 15:30.

\section{Egyéb források, dokumentumok:}

Balatoni Zászlóshajó Program - Egész évben Balaton. $2007.05 . \quad 31$. http://www.balatonregion.hu/balatoni_gazdasagi_forum/public/menu.php?m=388 letöltés ideje: 2013. augusztus 23. 10:12

„Lendületben az ország 2004-2006. A Köztársaság Kormányának programja a szabad és igazságos Magyarországért." http://img.index.hu/cikkepek/0409/belfold/kormprog.pdf letöltés ideje: 2013. szeptember 9. 17:00

Országgyülési felszólalások - www.parlament.hu

„ Új Magyarország - Szabadság és szolidaritás. A Magyar Köztársaság Kormányának Programja a sikeres, modern és igazságos Magyarországért 2006-2010. “ http://szmm.gov.hu/main.php?folderID=1055\&articleID=6205\&ctag=articlelist\&iid $=1$ letöltés ideje: 2013 . szeptember 9. 17:00

Regionális Operatív Programok Társadalmi Egyeztetése - Szerkesztett változat. Budapest, 2006. november.8. (www.nfu.hu/download/917/rop_egyeztetes_06\%5B1\%5D.11.08.doc)

ROP Akciótervek: http://www.nfu.hu/doc/1380

Simon Károly: Vita Oláh Miklóssal a Balaton régióról. Comitatus - Önkormányzati Szemle. 2005. XV.évf. 7. szám. 87. p. 